\title{
Intertextuality in Action: The Role of Expert Advice in Everyday Parenting
}

\author{
Alla V. Tovares \\ Howard University, \\ Washington, DC, USA \\ atovares@howard.edu
}

Received March, 02, 2020; Accepted May, 27, 2020

\begin{abstract}
This article explores the relationship between discourse and action by examining the role of expert advice in everyday parenting practices. Drawing upon the notions of dialogicality (Bakhtin, 1981), intertextuality (Kristeva, 1986), and repetition (Tannen, 2007) and incorporating insights from Mediated Discourse Analysis (e. g., Scollon, 1998; Scollon and Scollon, 2007; Norris and Jones, 2005), this work analyzes instances in which the actions of parents in three American families can be traced back to various public texts on parenting. Such relationship between text and action is identified as intertextuality in action (Author, 2005, 2020), or when public texts serve as resources for the verbal and non-verbal everyday actions of parents. It is further suggested that by adopting a positive, childcentered approach to parenting from literature and trained childcare professionals, parents themselves are socialized into the contemporary Discourse (Gee, 1999, 2015) of parenting. The analysis of the "repetition" of the words of experts in family (inter)actions also illuminates the dialogic relationship between the public and private spheres.
\end{abstract}

Key words: intertextuality, action, public discourse, expert advice, parenting, parental socialization, family interaction.

\section{Introduction}

This works explores the relationship between discourse and action by investigating the role of public texts in parenting. Specifically, it analyzes instances where bits of public texts on parenting from literature and trained childcare professionals resurface in parental actions of three American families. Drawing upon the notions of dialogicality (Bakhtin, 1981), intertextuality (Kristeva, 1986), and repetition in discourse (Tannen, 2007) and incorporating insights from Mediated Discourse Analysis (e.g., Scollon, 1998; Scollon and Scollon, 2007; Norris and Jones, 2005), this study zeros in on the instances in which public texts are "repeated" in everyday parenting actions, often without direct or specific references to the "original," or when public texts on parenting have become "one's own" parenting. I refer to this type of intertextual relation as intertextuality in action (Tovares, 2005, 2020). It is further argued that by integrating public texts on parenting from literature and childcare professionals into their own parenting actions, both verbal and nonverbal, parents adopt ideas and concepts of a positive, child-oriented approach to parenting and in so doing are themselves socialized into their generation's Discourse (Gee, 1999, 2015) of parenting. According to Gee, while (small-d) "discourse" refers to everyday interactions, (capital-D) "Discourse" includes "well integrated combinations of language, actions, interactions, objects, tools, technologies, beliefs, and values" (Gee, 2015: n.p.). 
While socialization, including family socialization, is a life-long process, the majority of the extant discourse-centered studies have primarily focused on how children are socialized into their families' worldviews (e.g., Ochs and Taylor, 1992; Blum-Kulka, 1997; Gordon, 2004; Kremer-Sadlik and Kim, 2007), leaving the socialization of parents largely underexplored. This study aims to start filling this gap by turning attention to parental socialization. Moreover, with the focus on everyday parenting actions, this study of intertextuality in action adds to our understanding of how the public and private spheres (Bourdieu, 1996; Habermas, 1989) are inextricably linked in (inter)action.

I begin by outlining the concepts of dialogicality, intertextuality, and text and address repetition in discourse. I then explore the notions of action and activity in relation to the studies of language followed by a discussion of the literature on the relationship between the public and private spheres and familial socialization. After introducing the data for this study, I analyze a set of representative examples of parents' verbal and nonverbal actions to demonstrate how expert advice is incorporated into how parents "do" parenting. The conclusion summarizes the findings, addresses what this study contributes to our understanding of the relationship between discourse and action and the role of expert advice in parental socialization. It also addresses this work's limitations and outlines directions for future research.

\section{Background \\ Dialogicality, intertextuality, text, and repetition}

Dialogicality is a central concept in the works of a Russian literary critic and philosopher Mikhail Bakhtin (e.g., 1981, 1984, 1986). Bakhtin's dialogicality captures the complex nature of human interaction where every word (and I add every action) is saturated with the overtones from prior (inter)actions. According to Bakhtin, dialogue is fundamental for both literary texts and everyday life, and any idea is distributed among many voices, many points of view. The related term, intertextuality - coined by a French semiotician Julia Kristeva - posits that "any text is constructed as a mosaic of quotations; any text is the absorption and transformation of another" (Kristeva, 1986: 37). In contemporary theorizing, the terms dialogicality and intertextuality are often used interchangeably, and many linguists have explored either or both of them, particularly in their studies of repetition in discourse (e.g., Tannen, 2007; Gordon, 2009, Gerhardt and Ayaß, 2012, to name but a few). Repetition, Tannen (2007: 101) contends in her influential work, is "a resource by which conversationalists together create a discourse, a relationship, and a world. It is the central linguistic meaning-making strategy, a limitless resource for individual creativity and interpersonal involvement." For Tannen, and for many scholars, repetition, dialogicality, and intertextuality are inextricably linked.

Moreover, in a number of studies the notions of text and intertextual repetition go beyond language to include other semiotic resources. For example, Kress (2000: 139) explores intertextuality in a variety of modes, language being one of them, and suggests that every text is the result of an intricate combination of intertwined social actions which themselves are rooted in complex social structures. In their work on media discourse, Meinhof and Smith (2000: 3) point out that a broad and inclusive understanding of intertextuality allows for the study of complex interactions 
between "texts" - their producers and audiences - and view "media discourse as being qualitatively continuous with the experience of everyday life." Meinhof and Smith (2000), like Kress, show the intertwined relationship between public texts and everyday talk and action. In my prior studies (Tovares, 2006, 2007, 2012), where I draw on the same dataset as I do in this work, I demonstrated how in everyday talk, family and friends recycle bits of television texts to negotiate their alignments and identities, display knowledge and beliefs, create involvement and entertainment, and socialize their children. In other words, I showed how public texts serve as resources in personal or private (inter)actions.

\section{Discourse and action}

To analyze intertextuality in action, I adopt the focus on activity and action from Mediated Discourse Analysis (MDA). MDA - an approach developed by Ron Scollon (1998, 2001a,b), often with in collaboration with Suzanne Scollon (Scollon and Scollon, 2005, 2007), and later expanded by other scholars (e.g., Norris and Jones 2005) - incorporates insights from practice theory (Bourdieu, 1977, 1990), Interactional Sociolinguistics (Gumperz, 1982; Tannen, 1984) and activity theory (Vygotsky,1978; Wertsch, 1991, 1998) by introducing a unifying unit of analysis - a mediated action. A mediated action is carried out with mediational means such as material objects, gestures, and language, with language being "the salient or most common of these mediational means" (Scollon, 2001b: 3). Mediational means are inherently interdiscursive, intertextual, and dialogic. With its focus on actions, MDA illuminates broader sociocultural and political issues. While MDA is a relatively new approach to discourse, the concepts of action and activity are not new to the study of language. By prioritizing activity and action and calling for a more in-depth exploration of the relationship between discourse and action, MDA foregrounds an idea that has interested linguists - as well as literary critics, psychologists, and other scholars in the humanities - for quite some time.

The eighteenth/nineteenth century linguist Wilhelm von Humboldt (17671835) suggested that language is better understood not as a product or an object (ergon), but as an activity (energia), which is constantly renewed in interactions (Matthews, 1997: 165). In his critique of the Saussurean view of language, Voloshinov (1973) argued that language is not a set of rules and structures, but a situated action. Philosophers Austin (1961) and Searle (1969) believed that language is used to perform actions. Their Speech Act Theory focuses on how action and meaning are related to language, and an utterance is conceived as an act by which a speaker does something (Schiffrin, 1994: 49). Studies in ethnomethodology (e. g., Garfinkel, 1967; Heritage, 1984) and Conversation Analysis (e. g., Atkinson and Heritage, 1984; Sacks, Schegloff, and Jefferson, 1974) focus on how people initiate, maintain, and terminate their relationships through interaction. As Sacks (1984: 415) observed, even something as mundane as "doing being ordinary" takes work, thus making it important to explore the question of ordinary actions.

Scollon and Scollon (2005) argue that addressing the question of how discourse becomes action and how action becomes discourse is an urgent task in discourse analysis. This paper takes up this task by demonstrating how public texts, 
such as the words of experts, "become" parents' daily actions and in so doing also addresses the relationship between the public and private spheres.

\section{The public and private spheres}

Researchers' understanding of the relationship between the public and private spheres ranges from segregated (e. g., Berger and Kellner, 1970) to interrelated (e. g., Goffman, 1959; Habermas, 1989; Bourdieu, 1996). Berger and Kellner (1970: 54) envisioned that with industrialization the private sphere would become more "segregated from the immediate controls of the public institutions." Habermas (1989), in contrast, saw economic and sociopolitical changes of the last two centuries as the primary reasons for the mutual infiltration between public and private. While for Berger and Kellner (1970: 56) family represents "its own segregated subworld, with its own closed conversations," for Habermas, family relations are the locus of the interpenetration of the public and private spheres. Similar to Habermas, Bourdieu (1996) stresses that family is inextricably linked to and often defined by sociopolitical and jurisdictional constructions. Likewise, Goffman (1959) understands the boundaries between public and private as porous and in flux. He suggests that while someone's home can be generally understood as what he calls a backstage region (the private sphere) where family members are relaxed, the same place can become a front stage region (the public sphere) in the presence of visitors. Moreover, as Calhoun (1999) argues, Habermas observed that early sentimental novels served as public resources for how people understood and learned to express their intimate or private feelings.

The idea that people draw on public resources in private or everyday interactions is further explored in media studies. For instance, in their research on the interpretation of the American television soap opera Dallas by viewers from different ethnic and cultural backgrounds, Katz and Liebes (1990) suggest that the viewers not only actively discussed the television program, but they also selectively incorporated television texts into their own lives. Related, Spitulnik (1997) demonstrates how different discourse styles and phrases from radio broadcast are subsequently recycled in everyday conversations in what she terms the social circulation of discourse. In this paper, building on prior research on the relationship between the public and private spheres, I turn my attention to everyday parenting actions and identify intertextual linkages between public texts on parenting and how parents "do" parenting and in so doing are themselves socialized into Discourse (Gee, 1999) of parenting.

\section{Parenting and parental socialization}

Following Arendell (1997), I understand parenting as an umbrella term that embraces different activities undertaken by adults who are involved in childrearing. Arendell (1997) maintains that parenting is not static, but a dynamic, socially defined phenomenon. Similarly, Ambert (1994: 530) states that in recent centuries parenting was "encoded in religious strictures, then moralized, medicalized, psychologized, psychiatrized, and more recently, legalized." Thus, what can be seen as natural or "common sense" parenting actions are in fact dialogic and intertextual 
amalgamations of different discourses. For example, Pitt's (2002) study of family literacy classes demonstrates that by learning how to be "good" mothers, women in the privacy of their own homes are governed by the public pedagogic discourse. Parental socialization, therefore, is also dialogically linked to the discourses of formal education.

Socialization can be viewed either narrowly or broadly. While in its narrow definition socialization refers primarily to the informal acquisition of knowledge, its broad definition includes both informal and formal knowledge acquisition. In this study, following Scollon and Scollon (1995), socialization is understood as all forms of cultural learning. It is worth mentioning that at the time of data collection, all three mothers whose discourse I analyze in this article were working on their respective graduate degrees in psychology or counseling. Moreover, two of them had work experience in clinical therapy. Thus, it is likely that these mothers incorporated knowledge from the classroom or the workplace into their everyday parenting practices (see Examples 8 and 9 in the analysis section of this paper). In her interview-based study of immigrant parents in Italy, Raffaetà (2015) observes that through parenting literature, television, and the internet, parents worldwide are socialized into child-centered, "intensive," or "competent" parenting that is guided by expert, "scientific" advice. She further suggests that the normalization of Western (or global north) parenting knowledge and discourses breaks "the division between public and private" and colonizes "the private spheres of life" (Raffaetà, 2015: 1193). Similarly, Strel'nik's (2015: 99) analysis of parenting advice by a popular Ukrainian pediatrician Komarovsky (in his books, TV programs, and social media), shows that expert knowledge is the key mechanism of how parenting is constructed in contemporary societies.

While a number of studies on family interaction have centered their analyses on how children are socialized into family norms and beliefs (Ochs and Taylor, 1992; Blum-Kulka, 1997; Gordon, 2004; Paugh, 2005; Fasulo, Loyd, and Padiglione, 2007; Tovares, 2010, and many others), socialization of parents has only recently attracted scholarly attention. Furthermore, the majority of the studies that focus on parental socialization rely on self-reports, interviews, observations, or public data, such as TV programs (e.g., Gordon, 2011; Raffaetà, 2015; Strel'nik, 2015; Sliepushova, 2020). In this regard, this paper adds to our understanding of parenting and parental socialization by considering everyday naturally occurring family interactions.

\section{Data and method}

Data for this study are drawn from a larger research project where adult members of four dual-career families audio-taped their daily interactions at home and at work for at least one week. ${ }^{1}$ All participants in the study were members of white, middle-class American families residing in the Washington, DC, area. The families not only recorded their daily interactions (in the absence of the researchers), but they were also observed (by the researchers) at work and at home for at least one day. The research team also interacted with the families and gained more information through follow-up visits and email exchanges. At the time of the recordings, each family had at least one child. In this paper, I only consider the 
participant families with small children: Kathy Patterson, Sam Foley and their daughter, Kira, two-years, one-month old at that time; Janet and Steve Neely-Mason and their two-year-eleven-month-old daughter Natalie; and Clara Shepherd, Neil Sylvan and their son Jason who was 4 years 10 months old. Additionally, at the time of taping both the Patterson/Foley and the Neely-Mason families were expecting a second baby.

I learned a great deal about the families' parenting simply by listening to their recordings, including the fact they read and relied on parenting literature. Analyzing the recorded interactions, I realized that because the bits of public texts on parenting are so seamlessly integrated into parental (inter)actions, it was not always easy to identify their "origins." To trace parents' words and actions to their "original" sources, I requested the lists of participants' favorite parenting books and magazines. Reading the books and magazines and listening to the recordings allowed me to link the sources of the parents' talk and actions to the books and magazines they were reading at the time of the recordings. I not only read the same parenting literature they read, but I also talked to and exchanged email messages with the participants and listened for any direct mentioning of parenting resources in their daily interactions. In what follows, I first outline the similarities in parenting practices among the three participating families. Then, using discourse analysis as a heuristic, I analyze a few representative examples to demonstrate how expert advice on parenting is incorporated into everyday parental actions.

\section{Analysis and discussion}

I began my analysis by listening to the recordings and studying the transcripts to identify what actions, verbal and non-verbal, parents undertake to perform parenting. Initial examination of the week-long recordings allowed me to distinguish the following similarities in parental actions and strategies in all three families:

1. parents promote positive behavior and use positive vocabulary;

2. parents reward children (verbally or with treats) for their good behavior and achievements;

3. to discipline their children, parents

a. give children "time-outs,"

b. give children choices,

c. do not use physical punishment or verbal humiliation;

4. parents seek advice on parenting from literature, childcare professionals, teachers, and networks of friends with children.

Later, when I read the books that were on the lists provided to me by parents and talked to them during follow-up visits, I was surprised at how much their parenting actions, including the ones outlined above, echoed parenting strategies discussed in the books and suggested by their childcare professionals. As note above in 1 , the general doctrine of parenting in all three families can be described as "positive parenting," which, as Raffaetà (2015) argues, has become a "normalized," global trend. Positive parenting centers on a child's individuality and independence, relies on positive reinforcement, and avoids the use of criticism and shame when molding a child's behavior. In what follows, I demonstrate the intertextual 
connections between parenting strategies suggested by childcare experts and the actions of parents. In other words, I explore intertextuality in action.

\section{Using positive labels for children's behavior}

My first two examples (Example 1 and 2) come from the family of Sam, Kathy, and their daughter Kira. During an informal chat when I visited them in their home, Kathy told me that though she and Sam have literature on parenting, they learned "the words and vocabulary of positive reinforcement" from their daughter's daycare professionals. For instance, instead of saying, "don't push" they learned to say "gentle touches." Kira is not a verbal child, so in their family interactions Kathy and Sam talk to and for her. During the two weeks of taping, Kathy and Sam used the phrase "gentle touch" twenty-two times. For instance, in the following excerpt Sam is driving Kira to a daycare center. Using the phrase "gentle touches" (line 3) Sam asks Kira not to pull his hair. It is worth mentioning that Sam has long hair and wears it in a ponytail.

\section{Example 1}

1. Kira: Wassat.

2. Sam: Dada's hair, dada's hair.

3. Gentle touches with dada's hair.

4. Oka:ys!

The action and expression "gentle touch" have become so familiar and widely used in this family that parents converted this expression into a verb, as the next example shows. In the following example Kathy, Sam and Kira are at home. It is evening and the family is spending time together. Sam calls Kathy's attention to how gentle Kira is to him:

\section{Example 2}

1. Sam: Look at her. Kath,

2. Kathy Awwwww.

3. Are you gentle touching Daddy.

4. That's so sweet.

$5 . \quad$ We love each other, don't we.

6. Sam: Awwwww.

$7 . \quad$ We love each other.

8. (to Kira)) You get kisses.

The excerpts above (Examples 1 and 2) show that the concept of "gentle touch" as a positive substitute for "don't pull or push" from a phrase borrowed from daycare professionals has become not only a part of Sam and Kathy's parenting vocabulary but also of their parenting actions. By appropriating the words of experts as their own parenting strategies and practices, Sam and Kathy also socialize each other into the type of parenting where positive reinforcement is the underlying approach to childrearing. It is worth noting that the childcare professionals themselves are guided by the public pedagogic discourses; therefore, by following 
the advice from their childcare professionals, the parents in this study are also albeit indirectly -influenced by and socialized into the discourses of formal, expertbased education.

While Sam and Kathy adopted positive parenting strategies from their daughter's daycare professionals, Janet and Steve indicated that they mostly rely on parenting books. Recordings show that Janet often reads to Steve excerpts from books on parenting. For instance, one evening Janet was reading aloud to Steve about "screaming and screeching" and "tantrums at three years." Natalie, who was two years, eleven-months old during the time of taping, had rather frequent temper tantrums, which greatly upset her parents, especially her mother. When I was at their house, I asked Janet and Steve if they had any literature on parenting. Steve replied that Janet owns a "library" on parenting. Janet mentioned that at the time of taping she was reading Raising Your Spirited Child: A Guide for Parents Whose Child is More Intense, Sensitive, Perceptive, Persistent, Energetic by Kurcinka (1998). Before she even finished her utterance, I was having what Tannen (1984) describes as the "aha" moment. I remembered that in the recordings Natalie was called "a spirited child" several times. In the book the term "spirited" describes children previously labeled "difficult." Kurcinka, by describing such children not as "less disciplined" but as "more intense, sensitive, perceptive," emphasizes the positive and stresses that it is important not only to introduce a positive term but to "practice, practice, practice" by which she means that parents have to incorporate positive terms and actions into their parenting. "Perceptive" is another term that the book promotes (it is also included in its title) and this family uses. In the following example (Example 3), Janet uses the word "perceptive" (line 14) to describe Natalie's behavior. Janet's brother Kevin babysat Natalie while Janet and Steve were at the hospital with Laura, Janet and Kevin's mother, who was seriously ill. When Janet and Steve came back from the hospital, Kevin reported that Natalie had been screaming.

\section{Example 3}

1. Janet:

Did she scream?

2. Kevin:

Oh yeah.

3. Janet:

4.

5.

6.

7.

I-we don't know what the screaming is, she just started doing it.

I would expect it when she was just turning two, but .. going on three,

everything I read says .. $\rightarrow$

8.

9. Kevin:

it's supposed to start settling down.

10. Steve: <yawning > Maybe it's her last hurrah.>

11. Janet:

12.

13.

14.

15.

Yeah maybe.

Well I think she- I think she's you know, partially .. picks up on ..

16.

17.

18. Kevin:

and I think she knows Mom's not been well, and .. picks up on the tension about that.

$\mathrm{Hm}$. 
Janet's explanation of Natalie's behavior is intertextually linked to the text of the book in which Kurcinka (1998: 136) states that spirited children are very perceptive: "their senses are keen, drawing in every aspect of the stimulation around them." By describing Natalie as "perceptive," Janet indicates that she chooses to view her daughter's behavior, even her temper tantrums, in a positive light and in doing so she follows the philosophy of "positive parenting." Another interesting aspect of this conversation is that Janet is directly indexing literature on parenting as her parenting resource for dealing with Natalie's screaming, "everything I read says it's supposed to start settling down" (lines 7-8).

In his work on family argument Lee (1997), through the lens of Cognitive Grammar, demonstrates that individual words can invoke conceptual frames or stand for the whole scene. Lee (1997) shows that conceptual frames involve particular "images" which are often tied to public discourse. Similarly, in this study when parents use words like "gentle touches," "a spirited child," and "a perceptive child," they are indexing a whole set of underlying beliefs about parenting as well as their stances towards these beliefs. For instance, parents' use of the words "spirited" and "perceptive" is a short-hand way of showing that while Natalie can be described as difficult or misbehaving, her parents choose to put a positive spin on her behavior. Parental use of such positive labels as euphemisms for badly behaved or noncompliant children can be described as metonymic. Specifically, these parents' choice of words indexes their overall style of parenting and frames their actions as "positive parenting." In sum, Example 1-3 above illustrate intertextuality in action, or when expert discourse has become a part of parental actions, both verbal and nonverbal. In the next section, I discuss how parents use positive reinforcement, another strategy of positive parenting, to teach and discipline their children.

\section{Using positive reinforcement to reward good behavior}

In Raising Your Spirited Child (Kurcinka, 1998) as well as in A Good Enough Parent (Bettelheim, 1988) and The Magic Years (Fraiberg, 1996), the parenting books which Steve identified as being on his and Janet's "A-list," the authors stress the importance of positive reinforcement when teaching or disciplining a child. At the time of the recordings, Natalie was being trained to use the toilet. In The Magic Years, Fraiberg (1996: 98) suggests that during potty training parents should encourage and remind children, approve their success, and disregard their failures. The recordings demonstrate that Janet and Steve were using positive reinforcement when potty training Natalie. In Example 4 below, Janet and Steve are about to leave the house, and Janet is giving last-minute instructions to Steve's sister Sylvia who has come to babysit Natalie.

\section{Example 4}

1. Janet: ((To Sylvia)) So. she's doin' pretty well keepin' her underwear dry,

2. but. usually we just try to ask her, you know, check in with her.

3.

4. Sylvia: And if she makes tinkles in the potty,

5. Janet: Uh-huh, ((to Natalie)) tell Aunt Sylvia, 

6. Natalie: When I make tinkles in the potty,
7. I get two M \& M's!
8. Janet: $\quad$ Two M \& M's,
9. Sylvia: Okay!
10. Janet: poops in the potty,
11. three M \& M's.
12. Sylvia: Oh boy.
13. Natalie: <laughs>
14. Janet: $\quad$ And the M \& M's container's <chuckling > over there.>

This example shows that Janet uses treats, in this case M \& M's chocolate candies, and verbal praise as positive reinforcement in Natalie's potty training. Janet's actions position her as a mother who is exercising positive parenting by rewarding her daughter's desired behavior and being patient with her progress. Furthermore, Natalie is aware that her good behavior will be rewarded (line 7 and 8). The recordings also show that when Natalie does not succeed, Janet, as Fraiberg's (1996) book recommends, does not punish or humiliate her, instead she just calls it "an accident." As evident from this example, Janet also respects Natalie's agency by including her in the process (line 2) "we just try to ask her, you know, check in with her." Including children in decision-making is also part positive parenting.

Similarly, during my visit with the third participating family (Neil, Clara, and Jason), Clara recalled that for Jason using a toilet was "a conscious choice." She said that she made sure that "he knew the concept" and showed him how to use the toilet, but, following the advice from Jason's teacher at the daycare center, she "did not put any pressure on him." So, when one day Jason overheard a conversation between his mother and a teacher about "big kids" who are potty trained being placed in one class and "little kids" who are not potty trained in the other, he started using the bathroom on his own. Clara, like Janet, followed expert advice and did not pressure Jason.

In this section, by juxtaposing parents' potty-training actions with expert advice, I was able to discern the dialogic and intertextual links between the two. In the next section, I continue the discussion of intertextuality in action, or the interrelationship between public texts on parenting and parents' actions, by looking at the parenting strategy of withdrawing positive reinforcement.

\section{Withdrawing positive reinforcement}

As I outlined earlier, the underlying principle of the expert advice from the contemporary books on parenting and childcare professionals is that of childoriented or positive parenting. Positive parenting focuses on a child's individuality, independence and above all on positive reinforcement, with behaviorism as one of its theoretical underpinnings. Behaviorist B.F. Skinner (1938) believed that children's behavior can be modified by granting rewards (positive reinforcement) or by withholding rewards. While in Example 4 we saw how positive reinforcement (M \& M's) was used to reward good behavior, in the following example, Clara applies the strategy of withholding a reward in order to send Jason a message that only good behavior is rewarded. It is Friday afternoon, Clara and Jason are coming back from the store where Jason repeatedly asked Clara to buy him "the gummy 
worms," "this lollipop," or just "something." However, Clara's answers to Jason's requests were "but not today," "not today," "well maybe next time." Earlier that same day, Jason did not behave well, kicking Clara twice and throwing a temper tantrum. In the following excerpt (Example 5) Clara, by refusing to buy Jason anything (withdrawing rewards) and by asking him to think about his actions, teaches him a lesson that his earlier behavior was unacceptable.

\section{Example 5}

$\begin{array}{ll}\text { 1. Jason: } & \text { Can I get a toy? } \\ \text { 2. Clara: } & \text { Um I don't think today. } \\ \text { 3. } & \text { Y'know why? } \\ \text { 4. Jason: } & \text { No. } \\ \text { 5. Clara: } & \text { Why- why do you think you can't get a toy today. } \\ \text { 6. Jason: } & \text { I don't know. } \\ \text { 7. } & \text { ((short pause) } \\ \text { 8. Clara: } & \text { You can't think of any reason at all? } \\ \text { 9. } & \text { Oh, } \\ \text { 10. } & \text { that's too bad, } \\ \text { 11. } & \text { that you can't think of any } \quad \text { [reason.] } \\ \text { 12. Jason: } & \text { [/Why] not./ } \\ \text { 13. Clara: } & \text { Y'know when we get toys? } \\ \text { 14. } & \text { It's usually after you've been a really good boy. } \\ \text { 15. } & \text { And you're a good boy right now, } \\ \text { 16. } & \text { but earlier I think we had an ISSUE, } \\ \text { 17. } & \text { didn't we. } \\ \text { 18. Jason: } & \text { <whiney> Yeah but- }\end{array}$

Initially Clara tries to elicit an answer from Jason about why he does not deserve a toy, "why do you think you can't get a toy today," "[y] any reason at all?" (lines 5 and 8). However, when Jason fails to provide an explanation, Clara reminds him about his bad behavior earlier that day or in her words "we had an issue" (line 16). In the conversation above, and numerous other times during the day, Clara kept reminding Jason about his misbehavior, "Do you think I would get somebody who kicked me, for the second time today, a present? I don't think so, Jason." As the following example (Example 6) shows, she also indirectly referred to Jason as "a mommy-kicker" later the same day when she and Jason were discussing what kind of people did not deserve presents.

\section{Example 6}

$\begin{array}{ll}\text { 1. Jason: } & \text { I'm not gonna give him a present- } \\ \begin{array}{ll}\text { 2. } & \text { if he's a killer or a hunter, } \\ \text { 3. } & \text { [or a (robber-)] } \\ \text { 4. Clara: } & \text { [What if he's] a mommy-kicker? } \\ \text { 5. Jason: } & \text { <laughs> } \\ \text { 6. } & \text { Yes. } \\ \text { 7. Clara: } & \text { <laughs loudly> } \\ \text { 8. } & \text { I don't think so. }\end{array}\end{array}$


By not buying Jason anything and talking about the reasons for not rewarding Jason's bad behavior and stressing that only "a really good boy" deserves rewards, Clara uses withdrawal from positive reinforcement as an educational tool and in so doing indexes her adherence to positive parenting. In the following section, I discuss "time out," another type of parenting strategy that can be described as withdrawal from positive reinforcement.

\section{Taking "time-out" from positive reinforcement}

As noted earlier, one of the parenting issues that Janet and Steve were facing at the time of the recordings were Natalie's temper tantrums. Literature on parenting, including the books that Janet and Steve reference (e.g., Kurcinka, 1998), suggests time-outs as an effective way of dealing with children's temper tantrums. During "time-outs" children are typically asked either to go to their room or to calm down and sit quietly and think about what they have done. While no rewards are given during a "time-out," neither is the punishment. Solter (1998) suggests that "time-out" evolved into a popular teaching tool when parents and educators became aware of the dangers of physical punishment. Janet and Steve deal with Natalie's temper tantrums by giving her time-outs. In the following excerpt (Example 7) Janet is getting Natalie ready for school. Natalie resisted putting on her tights and began to throw a temper tantrum. Janet uses a time-out to stop the escalating temper tantrum.

\section{Example 7}

1. Janet:

2.

3.

((to Natalie)) Okay put your footie in, ((in the tights)) okay so,

SO,

((lines 4-19: Janet tries to get Natalie to put on her tights))

20. Janet:

Oh come on Honey,

21. [I can't] reach.

22. Natalie:

[<whiney> No.>]

23.

$<$ whiney. No footie.>

24. Janet:

What's- stop.

25. Natalie:

26. Janet:

<wails loudly>

27. Natalie:

Natalie!

28. Janet:

<wails loudly>

29. Natalie:

Hey!

30.

31. Janet:

<whines/cries>

32.

<whiney> You [ (?) me.>]

[What is-]

33. Natalie:

what is your problem.

34. Janet:

<whiney> No tights!>

35. Natalie:

Honey you've got to wear tights, it's cold out.

36. Janet:

$<$ whiney > No >

37.

$<$ louder> Natalie STOP IT!

38.

Do you need a time-out?

39. Natalie: <whiney, quiet > Yeah.> 

40. Janet: Huh?
41. Natalie: <whiney> Yeah.>
42. Janet: You do?
43. Natalie: <whiney> Yeah.>
44. Janet: $\quad$ All right, go sit down.
45. Natalie: $\quad\langle$ whines $\rangle\langle$ cries $>$
46. Janet: Sit down.
47. Natalie: <cries loudly $><$ screams $>$
48. Janet: When you're ready to collect yourself, come sit on my lap.

Janet's actions are aligned with parenting based on positive reinforcement. She issues a "time-out" for Natalie to calm down, and until Natalie is ready to "collect" herself (line 48), Janet refuses to encourage her.

It is worth mentioning that "time-out" as a parenting strategy has its advocates and critics among childcare specialists. Some critics of "time-out" find it to be either too harsh or too ineffective as children are not able to express their opinions and do not learn self-discipline (see Solter, 1998 for a discussion). These different, and somewhat contradictory, opinions on "time-out" among specialists are reflected in the actions of parents who participated in this study, as my next two examples demonstrate.

As I mention earlier, parents in this study identified educators and childcare professionals as parenting resources. In the following example, on her way to work, Clara ran into her acquaintance Jennifer on public transportation. The two women are talking about how they discipline their children. Both women, in line with positive parenting, indicate that they give their children choices to regulate their behavior. Clara notes that her son's teacher, Ms. Ross, advised against using "timeout" with Jason.

\section{Example 8}

1. Clara: But you know the big thing Ms. Ross got me to stop doing-

2. Jennifer: Uh-huh?

3. Clara: because I worked with kids for many years in mental health.

4. Jennifer: Uh-huh.

5. Clara: And we used time-outs all the time. She told me not do that with Jason.
6. Jennifer: Uh-huh.

7. Clara: And it was the best thing. Because Jason was just doing um you know,

8. Jennifer: I know, he was like "Oh I can get away with this."

9. Clara: He would just do you know cost-benefit ratio,

$10 . \quad$ and get, well you know,

11. "five minutes and I could you know burn down the building" you know.

12. Jennifer: Right.

13. Clara: "And all I have is a five-minute time-out.

14. So what the heck." 
In the excerpt above, Clara claims that a specialist influenced her parenting strategies. It is interesting that the authority of Ms. Ross as a childcare professional overrides Clara's professional experience in mental health where the concept of "time-out" was a standard practice and was not perceived negatively (line 5). In addition, Clara's personal experience with Jason, who was doing a "cost-benefit ratio" (lines 9-11 and 13-14), influences Clara's parenting. However, as my next example shows (Example 9), this does not mean that "time-out" is completely absent from Clara and Neil's parenting repertoire.

\section{“Time-out" revisited}

Analysis of the weeklong recordings often reveals differences between what parents report they are doing as parents and what they actually do. The unique data set allowed me to notice several discrepancies between parental verbal and nonverbal actions (parenting) and how they talk about parenting (what I call metaparenting). For instance, in the interaction above, Example 8, Clara tells her acquaintance Jennifer that Jason's teacher convinced her to stop giving Jason timeouts to correct his undesired behavior. The aforementioned conversation between Clara and Jennifer occurred on Monday. On Wednesday of the same week Clara gave Jason a time-out and sends him to his room because he was misbehaving. Disregarding his time-out (he was supposed to be upstairs in his room), Jason comes down:

\section{Example 9}
1. Jason:
Peek-a-boo:!
2. Clara:
Oh, you didn't listen to me?
3.
You just came down anyway?
4. Jason:
Ah-ah-hah
5. Clara:
Well, I think you need to (sit for) time out, for [(??)]
6. Jason:
[No:] No, no,
7. Neil:
[Well- we get-]
8. Clara:
[I told him to stay] up here with Daddy,
9. Jason:
But then, I won't do it [(?? ??)]
10. Clara: [<raised voice> If you don't]> go to time-out now, 11. you won't go to the party. Go in time-out, [now.]
12. Jason: [(Yes, but thi:s, )]
13. [But thi:s]
14. Clara:
[In your roo:m]

Clara not only gives Jason a time-out (lines 5, 10, and 11), but she also warns him that he would not be allowed to go to the party (withdrawing positive reinforcement) if he does not "go in time-out" (line 11). The discrepancy between Clara's claim that she stopped giving Jason time-outs (Example 8) and her actual actions of giving time-out to discipline her son (Example 9) demonstrates the complexity of parenting, and human actions in general. It also calls attention to the importance of obtaining continuous uninterrupted recordings which can capture a variety and complexity of participants' actions. Clara's actions also indicate that 
self-reports, which are often used to study parenting and other activities, may not be consistent with actual actions and practices. In the case of time-outs, Clara's parenting and metaparenting are in conflict: While her metaparenting shows what actions and strategies she associates with good parenting (based on expert advice), her actions show how she actually "does" parenting. I suggest that the juxtaposition of parenting and metaparenting gives a more comprehensive idea of the complex nature of parenting where the different public and private voices create an everevolving dialogue, and different texts serve as resources for intertextuality in action. In the following section, I demonstrate how parents navigate various, and often conflicting, expert advice on parenting and at the same time construct their own expertise.

\section{Parents' selective incorporation of expert advice}

As noted above, parenting is a dynamic phenomenon shaped by the underlying principle of "what is good for children" (Ambert, 1994). In turn, "what is good for children" is (re)defined by numerous experts in child development, medical, nutritional, legal, and other specialists. Parents are bombarded by diverse and sometimes contradictory advice from childcare experts. This multitude of sources both puts pressure on parents to be more knowledgeable and allows them to choose child-rearing practices that best correspond to their general beliefs. For instance, some family members in the study are socialized into anti-establishment discourses by buying organic food (e.g., Kathy and Sam) or switching to a vegetarian diet (e. g., Clara, Neil and Jason; Steve). Neil, Clara, and Jason, after some media revelations about the way food is made at MacDonald's restaurants, stopped going to MacDonald's where animal products could be present in vegetarian dishes. The latter is a telling example of how public texts influence family actions, in this case family dietary choices.

In what follows I demonstrate how the literature on the "back to nature" and anti-establishment parenting influenced Kathy and Sam's actions as parents. Their family, unlike other families in the study, sleep in one "family bed," and their daughter Kira is expected to be nursed as long as she asks for it. When I emailed Kathy asking where she and Sam got the ideas of a family bed and extended breastfeeding, she wrote that even before she became pregnant with Kira, she read and was influenced by Milk, Money, and Madness: The Culture and Politics of Breastfeeding (Baumslag and Michels, 1995). In the book, along with presenting the advantages of breastfeeding, the authors promote the idea of the whole family sleeping together in one bed as a way of creating closeness. She also was periodically reading Mothering, a magazine that advocates "natural mothering" and attachment parenting (e. g., sleeping in a family bad, breastfeeding, homeschooling, etc.). During the time the recordings were made Kathy was eight months pregnant with her second daughter. Kathy chose a midwife, not a doctor, for most of her prenatal care. In the following interaction, Kathy is at one of her regular visits with her midwife. The midwife - whose family also sleeps in a family bed - and Kathy agree that her new baby needs to sleep with her parents and sister in the "family bed." 


\section{Example 10}

1. Midwife:

2.

3.

4. Kathy:

5. Midwife:

6.

7. Kathy: Right,

8. Midwife:

9.

10. Kathy:

11.

12. Midwife:

13. Kathy:

14. Midwife:

15.

16. Kathy:

17. Midwife:

18.

20. Kathy:

21. Midwife:

22.
Yeah, I don't understand why are kids EXILED like that-

You know, traditionally in this country, you know,

It's like, INFANTS,

$<$ laughs>

Little teeny infants,

And put them in a ho- a bedroom down the- the ha- hallway!

COMPLETELY down the hallway!

That just blows my mind!

\section{Y'know, I never knew I was gonna be-}

Do the family bed until I had a baby-

It just felt right.

My instincts just took over

That was the same for me,

And my mother. was . (totally against it)

My mother-

((animating) "When are you going to get that be-

That baby out of your bed!" bla bla bla

Yeah.

And I just told her like, "You know?

It feels RIGHT to me."

Both Kathy and the midwife point out that it is unnatural to leave a baby in a room all alone at night, which is a typical practice in many American families. Kathy, by stating that her "instincts just took over" (line 13), makes clear that she believes that it is against nature to separate parents and children for the night. She also points to her transformation into a parent who follows "natural" mothering, "I never knew I was gonna be- Do the family bed until I had a baby-" (lines 10 and 11). By emphatically comparing "little teeny infants" who sleep in their own beds to being "EXILED" (lines 1-5), the midwife frames the traditional approach of babies sleeping in separate rooms as negative. It is noteworthy that three days after this appointment, Kathy and Sam - in preparation for their new baby -bought a bigger "family bed."

Kathy's actions, including extended breastfeeding of Kira, having a family bed, and having a midwife, position and socialize her within an "anti-establishment" and "back to nature" approach to parenting. However, this does not mean that once parents accept a particular "trend" or "school" of childrearing, they unquestionably follow its expert advice. For instance, Kathy told me that while she follows the advice offered in Mothering, she does not agree with some of the suggestions found on the pages of this magazine, such as abstinence from vaccinations, because she believes that "medical progress should not be ignored." Kathy's actions indicate that she selectively incorporates public texts about childrearing into her parenting actions and in so doing underscore the active, agentive role of parents in intertextuality in action. 


\section{Conclusion}

The goal of this paper was to investigate intertextuality in action. Specifically, I have centered my analysis on how parents incorporate public texts on childrearing into their own parenting actions, both verbal and nonverbal. Drawing on Bakhtin's (1981) and Kristeva's (1986) ideas of the dialogic and intertextual nature of human interaction, I have demonstrated how public advice on parenting is dialogically and intertextually linked to everyday parenting actions. This investigation of the habitual actions of the parents in three families illuminates the integral role of public texts as valuable resources in how parents "do" parenting. In his work on media and intertextuality, Bachmair (2000) compares contemporary televiewing to a selfservice buffet from which the viewers select what to integrate into the "text" of their everyday lives. To a certain degree, the actions of the parents in this study show that advice on parenting can be compared to a self-service buffet that offers a number of choices from which parents pick and choose strategies that appeal to them, and in the process of their everyday (inter)actions they also alter these strategies to accommodate their own values, beliefs, and actions. However, parents' choices are not value neutral nor are they detached from the public sphere. Medical, child development, and other discourses come into play and influence parental actions. Thus, each family's parenting actions and practices demonstrate hybridity (Bakhtin, 1981): they share features with those of other contemporary parents and public discourse on parenting yet remain undeniably distinct.

This work adds to our understanding of dialogicality, intertextuality, and repetition by showing linkages between discourse and action. By extending the scope of analysis to include action, this paper shows that intertextual and dialogic relations exist beyond conventional texts. For instance, parents' everyday actions, such as giving a misbehaving child a "time-out," rewarding children's good behavior with sweets, and having all family members sleep in a family bed are intertextually linked to public expert advice. In other words, public texts on parenting are "repeated" in parents' everyday actions, the process I identify as intertextuality in action.

Furthermore, my analysis of the daily (inter)actions shows that parenting is essentially dialogic, and parents not only borrow from but also add their voices to the ongoing dialogue on parenting. Put differently, parental actions are reflections and refractions of public texts on parenting. In their actions, parents interweave their own knowledge gained from the actual parenting experiences with the information they have selected from public texts on parenting, sometimes overruling one expert either in favor of another expert or their own expertise. Additionally, this study points to the importance of having access to different types of data. For instance, the juxtaposition of ethnographic observations, public texts, and everyday naturally occurring family interactions allowed me to capture the complexities and contradictions of parenting.

Finally, my analysis also demonstrates that Janet and Steve, Clara and Neil, and Sam and Kathy socialize themselves and their spouses into the contemporary Discourse (Gee, 1999) of parenting through the selective appropriation of expert advice from books and childcare specialists. All their actions, such as buying and reading parenting books and magazines, sleeping in a family bed, giving children "time-outs" and others are interdiscursively, intertextually, and dialogically united 
by the notion of positive parenting. Parents' actions simultaneously produce and reproduce the Discourse of parenting that is based on positive reinforcement and is expert driven.

While offering valuable insights, this work has limitations. For instance, it primarily focuses on two types of parenting resources: childcare professionals and print media (books and magazines). The rapid development of technology and the omnipresent nature of new media, social media in particular, have undoubtedly influenced how and from whom modern parents seek and accept advice. Furthermore, this study considers parents from one (sub)culture: white, middle-class Americans. Future studies should consider more, and diverse, families and from various (sub)cultures and include different media.

$\begin{array}{ll}((\text { words })) & \text { Double parentheses enclose transcriber's comments } \\ \text { (words) } & \text { Single parentheses enclose uncertain transcription } \\ \text { carriage return } & \text { Each new line represents an intonation unit } \\ \rightarrow & \text { An arrow indicates that the intonation unit continues to } \\ \text { the next line } & \\ - & \text { A dash indicates a truncated word } \\ ? & \text { A question mark indicates a relatively strong rising } \\ & \text { intonation } \\ \cdot & \text { A period indicates a falling, final intonation } \\ , & \text { A comma indicates a continuing intonation } \\ : & \text { Dots indicate silence } \\ \text { CAPS } & \text { A colon indicates an elongated vowel } \\ <\text { laughs> } & \text { Capitals indicate emphatic stress } \\ \text { Amanner> words> } & \text { Angle brackets enclose descriptions of vocals noises, e.g. } \\ & \begin{array}{l}\text { laughs } \\ \text { Angle brackets enclose descriptions of the manner in }\end{array} \\ \text { which an utterance is spoken, e. g., high pitched, } \\ \text { words [words] } & \text { laughing, incredulous } \\ \text { [words] } & \text { Square brackets enclose simultaneous talk }\end{array}$

\section{Notes}

1. The project Balancing work and family: Creating parental identities through talk was supported by the Alfred P. Sloan Foundation and co-directed by Shari Kendall and Deborah Tannen. I served as a research assistant on the project. To protect the identities of the participants, their names and the names of their friends, relatives, coworkers, and pets were substituted with pseudonyms.

2. The following transcription conventions were developed by Shari Kendall and Deborah Tannen for use in the research project Balancing work and family: Creating parental identities through talk, at Georgetown University. 


\section{References}

Ambert, Nina-Marie. 1994. “An international perspective on parenting: Social change and social constructs." Journal of Marriage and the Family, 56(3): 529-543.

Arendell, Terry. 1997. "A social constructionist approach to parenting." Contemporary parenting: Challenges and issues, edited by Terry Arendell, 1-44. Thousand Oaks, CA: Sage Publications.

Atkinson, Maxwell and John Heritage, eds. 1984. Structures of Social Action: Studies in Conversation Analysis. Cambridge: Cambridge University Press.

Austin, John. 1961. How to Do Things with Words. Oxford: Clarendon Press.

Bachmair, Ben. 2000. "Creator spiritus: Virtual texts in everyday life." In Intertextuality and the Media, edited by Ulrike H. Meinhof and Jonathan Smith, 115-131. Manchester and New York: Manchester University Press.

Bakhtin, Mikhail. 1981. The Dialogic Imagination. Austin: University of Texas Press.

Bakhtin, Mikhail. 1984. Problems of Dostoevsky's Poetics. Minneapolis, MN: University of Minnesota Press.

Bakhtin, Mikhail. 1986. Speech Genres and Other Late Essays. Austin, TX: University of Texas Press.

Baumslag, Naomi and Dia Michels. 1995. Milk, Money, and Madness: The culture and Politics of Breastfeeding. Westport, CT: Bergin \& Garvey.

Berger, Peter and Hansfried Kellner. 1964. "Marriage and the construction of reality: An exercise in the microsociology of knowledge." Patterns of Communicative Behavior, edited by Hans Peter Dreitzel, 49-72. New York: Macmillan.

Bettelheim, Bruno. 1988. A Good Enough Parent: A Book on Child-rearing. New York: Vintage Books.

Blum-Kulka, Shoshana. 1997. Dinner Talk: Cultural Patterns of Sociability and Socialization in Family Discourse. Mahwah, NJ: Lawrence Earlbaum Associates.

Bourdieu, Pierre. 1977. Outline of a Theory of Practice. Cambridge: Cambridge University Press.

Bourdieu, Pierre. 1990. The Logic of Practice. Stanford, CA.: Stanford University Press.

Bourdieu, Pierrre.1996. "On the family as a realized category." Theory, Culture and Society 13(3): 19-26.

Calhoun, Craig. 1999. "Introduction: Habermas and the public sphere." Habermas and the Public Sphere, edited by Craig Calhoun, 1-50. Cambridge, MA: MIT Press.

Fasulo, Alessandra, Heather Loyd and Vincenzo Padiglione. 2007. "Children's socialization into cleaning practices: A cross-cultural perspective." Discourse \& Society 18(1): 11-33.

Fraiberg, Selma. 1996. The Magic Years. New York: Charles Scribner's Sons.

Garfinkel, Harold. 1967. Studies in Ethnomethodology. Englewood Cliffs, NJ: Prentice Hall.

Gee, James Paul. 1999. An Introduction to Discourse analysis: Theory and Method. London: Routledge. 
Gee, James Paul. 2015. Discourse, Small d, Big D. The International Encyclopedia of Language and Social Interaction, edited by Karen Tracy, Todd Sandel and Cornelia Ilie. https://doi.org/10.1002/9781118611463.wbielsi016

Gerhardt, Cornelia and Ruth Ayaß, eds. 2012. The Appropriation of Media in Everyday Life: What People Do with Media. Amsterdam and Philadelphia: John Benjamins Publishing.

Goffman, Erving. 1959. The Presentation of Self in Everyday Live. Garden City, NY: Doubleday.

Gordon, Cynthia. 2004. “'Al Gore's our guy': Linguistically constructing a family political identity." Discourse \& Society, 15(5): 607-631.

Gordon, Cynthia. 2009. Making Meanings, Creating Family: Intertextuality and Framing in Family Interaction. New York: Oxford University Press.

Gordon, Cynthia. 2011. "Impression management on reality TV: Emotion in parental accounts." Journal of Pragmatics, 43: 3551-3564.

Grant, Julia. 1998. Raising Baby by the Book: The Education of American Mothers. New Haven: Yale University Press.

Gumperz, John. 1982. Discourse Strategies. Cambridge: Cambridge University Press.

Habermas, Jurgen. 1989. The Structural Transformation of the Public Sphere: An Inquiry into a Category of Bourgeois Society. Cambridge,

Heritage, John. 1984. Garfinkel and Ethnomethodology. Cambridge, MA: Polity.

Katz, Elihu and Tamar Liebes. 1990. The Export of Meaning: Cross-cultural Readings of Dallas. New York and Oxford: Oxford University Press.

Kremer-Sadlik, Tamar and Jeemin Lydia Kim. 2007. "Lessons from sports: Children's socialization to values through family interaction during sports activities." Discourse \& Society, 18: 35-52.

Kress, Gunther. 2000. "Text as the punctuation of semiosis: Pulling at some of the threads." In Intertextuality and the Media, edited by Ulrike H. Meinhof and Jonathan Smith, 132-154. Manchester and New York: Manchester University Press,

Kristeva, Julia. 1986. "Word, dialog and novel." The Kristeva Reader, edited by Tori Moi, 34-61. New York: Columbia University Press.

Kurcinka, Mary Sheedy. 1998. Raising your Spirited Child: A Guide for Parents whose Child is More Intense, Sensitive, Perceptive, Persistent, and Energetic. New York: Harper Perennial.

Lee, David. 1997. "Frame conflicts and competing construals in family argument." Journal of Pragmatics, 27: 339-360.

Matthews, P. H. 1997. The Concise Oxford Dictionary of Linguistics. Oxford and New York: Oxford University Press.

Meinhof, Ulrike H. and Jonathan Smith. 2000. "Spitting image: TV genre and intertextuality." Intertextuality and the Media, edited by Ulrike H. Meinhof and Jonathan Smith, 43-60. Manchester and New York: Manchester University Press.

Norris, Sigrid and Rodney Jones, eds. 2005. Discourse in Action: Introducing Mediated Discourse Analysis. New York: Routledge.

Ochs, Elinor and Carolyn Taylor. 1992. "Family narrative as political activity." Discourse \& Society, 3(3): 303-340.

Paugh, Amy L. 2005. "Learning about work at dinnertime: Language socialization in dual-earner American families." Discourse \& Society, 16(1): 55-78. 
Pitt, Kathy. 2002. "Being a new capitalist mother." Discourse \& Society 13(2): 251-267.

Raffaetà, Roberta. 2015. "My parents never spent time with me! Migrants' parents in Italy and hegemonic ideals of competent parenting." Journal of Family Issues, 36(9): 1192-1211.

Sacks, Harvey. 1984. "On doing being ordinary," in Structures of Social Action: Studies in Conversation Analysis, edited by Maxwell Atkinson and John Heritage, 413-429. Cambridge, UK: Cambridge University Press.

Sacks, Harvey, Emmanuel Schegloff and Gail Jefferson. 1974. "A simplest systematics for the organization of turn-taking for conversation." Language, 50: 696-735.

Schiffrin, Deborah. 1994. Approaches to Discourse. Oxford and Cambridge: Blackwell.

Scollon, Ron. 1998. Mediated Discourse as Social Interaction. A Study of News Discourse. London and New York: Longman.

Scollon, Ron. 2001a. Mediated Discourse. The Nexus of Practice. London and New York: Routledge.

Scollon, Ron. 2001b. "Action and text: Toward an integrated understanding of the place of text in social (inter)action." Method in Critical Discourse Analysis, edited by Ruth Wodak and Michael Meyers, 41-19. London: Sage.

Scollon, Ron and Suzie Wong Scollon. 1995. Intercultural Communication. Malden, MA and Oxford, UK: Blackwell Publishers.

Scollon, Ron and Suzie Wong Scollon. 2005. "Lighting the stove: Why habitus isn't enough for Critical Discourse Analysis." A New Agenda in (Critical) Discourse Analysis, edited by Ruth Wodak and Paul Chilton, 101-117. Amsterdam: John Benjamins.

Scollon, Ron and Suzie Wong Scollon. 2007. "Nexus analysis: Refocusing ethnography on action." Journal of Sociolinguistics, 11(5): 608-625.

Searle, John. 1969. Speech Acts. Cambridge: Cambridge University Press.

Skinner, B. F. (Burrhus Frederic). 1938. The Behavior of Organisms. New York and London: Appleton-century Company, INC.

Sliepushova, Anhelina. 2020. "Dyskurs batko-dytyna v animatsiinomu seriali 'Family Guy': Korpusnyi analiz.' Synopsys: Tekst, kontekst, media, 26(2): 61-65.

Solter, Aletha. 1998. Tears and Tantrums. Goleta, CA.: Shining Star Press.

Spitulnik, Debra. 1997. "The social circulation of media discourse and the mediation of communities." Journal of Linguistic Anthropology, 6(2): 161-187.

Strel'nik, Elena. 2015. "Zhyzn po doktoru Komarovskomu”: Konstruirovanie roditelstva v sovetah po ukhodu za detmi”. Laboratorium, 7(2): 83-105.

Tannen, Deborah. 1984. Conversational Style: Analyzing talk among friends. Norwood, New Jersey: Ablex Publishing Corporation.

Tannen, Deborah. 2007. Talking voices: Repetition, dialogue, and imagery in conversational discourse. New York: Cambridge University Press.

Tovares, Alla. 2005. "Intertextuality in family interaction: Repetition of public texts in private settings." $\mathrm{PhD}$ diss., Georgetown University, Washington, DC.

Tovares, Alla. 2006. "Public medium, private talk: Gossip about a TV show as "quotidian hermeneutics." Text \& Talk, (4): 463-491.

Tovares, Alla. 2007. "Family members interacting while watching television." Family talk: Discourse and Identity in Four American Families, edited by Deborah 
Tannen, Shari Kendall, and Cynthia Gordon, 283-310. New York and Oxford: Oxford University Press.

Tovares, Alla. 2010. "All in the family: Small stories and narrative construction of a shared family identity that includes pets." Narrative Inquiry, 20 (1): 1-19.

Tovares, Alla. 2012. "Watching out loud: A television quiz show as a resource in family interaction." The Appropriation of Media in Everyday Life: What People Do with Media edited by Cornelia Gerhardt and Ruth Ayaß, 107-130. Amsterdam and Philadelphia: John Benjamins Publishing.

Tovares, Alla. 2020. "The art of the insult: (Re)creating Zaporizhian Cossacks' letter-writing on YouTube as collective creative insurgency." Language of Conflict: Discourses of the Ukrainian Crisis, edited by Natalia Knoblock, 213-232. London: Bloomsbury Academic.

Voloshinov, Valentin. 1973. Marxism and the Philosophy of Language. New York and London: Seminar Press.

Vygotsky, Lev. 1978. Mind in Society: The Development of Higher Psychological Processes. Cambridge, MA: Harvard University Press.

Wertsch, James. 1991. Voices of the Mind: A Sociocultural Approach to Mediated Action. Cambridge, MA: Harvard University Press.

Wertsch, James. 1998. Mind as Action. New York: Oxford University Press. 